\title{
Melawan Etika Lingkungan Antroposentris Melalui Interpretasi Teologi Penciptaan Sebagai Landasan Bagi Pengelolaan-Pelestarian Lingkungan
}

\author{
Yusup Rogo Yuono ${ }^{1 *}$ \\ 1) Sekolah Tinggi Teologia Sangkakala \\ ${ }^{*}$ Korespodensi Penulis: yusupyuono@gmail.com
}

Received: 27 May 2019 / Revised: 18 June 2019 / Accepted: 18 June 2019

\section{Abstrak}

Etika lingkungan memfokuskan diri pada bagaimana perilaku manusia yang seharusnya terhadap lingkungan. Dalam etika ini makluk nonmanusia mendapatkan perhatian. Etika lingkungan sekaligus merupakan kritik atas etika yang selama ini dianut manusia yang membatasi diri pada komunitas sosial. Dalam dimensi ekoteologi melihat bahwa krisis lingkungan yang sekarang ada tidak lepas dari sikap dan perspektif manusia terhadap alam. Manusia modern memandang alam sebagai obyek yang harus dieksploitasi demi tercukupinya kebutuhan tanpa memikirkan dampaknya. Penelitian ini hendak menggali pandangan kekristenan terhadap alam. Kekristenan percaya bahwa alam merupakan ciptaan Tuhan. Manusia diberi mandat untuk menguasai dan mengusahakan. Pemahaman yang keliru sering kali menimbulkan perilaku salah dalam pemanfaatan alam. Kekristenan perlu memberikan pandangannya sebagai usaha preventif maupun represif, bagaimana seharusnya perilaku manusia terhadap alam. Kata kunci: etika, ekoteologi, etika lingkungan

\section{Abstract}

Environmental ethics focuses on how humans behave against the environment. In this matter, non-human beings get attention. Environmental ethics is also one of the most important in social communities. In the 
ecotourism dimension see that the existing environmental crisis is inseparable from human attitudes and expressions of nature. Modern humans view nature as an object that must be exploited for the sake of sufficiency of the speed without the impression of its impact. This research is to carry out the view of Christianity on nature. Christianity believes that nature is God's creation. Humans are given the mandate to master and strive. Misunderstanding often calls for wrong use of nature. Christianity needs to provide a view as a preventive or repressive effort, how to touch human behavior towards nature.

Keywords: ethics, ecotourism, environmental ethics

\section{Pendahuluan}

Permasalahan Ekologis

Bumi sebagai tempat tinggal seluruh makluk menghadapi kerusakan yang semakin serius. "Kemerosotan kualitas fisik planet bumi terbukti berasal dari berbagai fenomena yang saling berhubungan seperti deforestasi dengan laju yang cepat, desertifikasi, salinitas tanah, hilangnya keanekaragaman hayati, kekurangan air tawar dan khususnya perubahan iklim"1. Penyebab pokok dari krisis bumi/lingkungan hidup ini adalah pola pendekatan manusia modern terhadap alam yang keliru. Manusia kurang memperlakukan alam sebagai sahabat dan hanya melihat sebagai obyek semata-mata. Alam dipandang sebagai sarana, tambang kekayaan, sumber energi, sumber kekayaan yang memang harus diekspoitasi bagi kebutuhan manusia. Inilah yang menyebabkan kerusakan lingkungan semakin parah. Etika lingkungan muncul sebagai reaksi terhadap penafsiran firman Allah yang membenarkan praktek ekspoitasi alam tanpa batas sehingga menimbulkan krisis lingkungan. Manusia kurang sadar, "dengan merusak alam ciptaan, manusia sebenarnya sedang menghancurkan peradaban dirinya sendiri"'.

Jika dilihat dari sudut pandang kekristenan, dapat dikatakan topik kerusakan lingkungan hampir tidak pernah mendapatkan perhatian. Gereja

${ }^{1}$ Guess, Deborah."An Ecotheological Exploration of the Thought of Arthur Peacocke," Journal of Anglican Studies 15, no. 2 (Februari 2017): 188-206, diakses 09 November 2018 https://doi.org/10.1017/S1740355316000279.

${ }^{2}$ Lukas Awi Tristanto. Panggilan Melestarikan Alam Ciptaan. (yogyakarta. Kanisius. 2015), 78 
melalui kotbah dan pesan-pesan dari mimbar minim membahas topik ini, padahal lingkungan merupakan tempat penting bagi kelangsungan hidup umat dan makluk lain. Salah satu penyebabnya yaitu konsep keselamatan yang hanya memperhatikan aspek keselamatan jiwa saja. Keselamatan tidak dipandang secara utuh dan holistik, sehingga keselamatan lingkungan tidak mendapat tempat dan perhatian. Corak teologi yang hanya membahas Tuhan belaka tanpa memperhatikan ciptaan, bukanlah teologi yang kuat. Sunarko dan A. Eddy Kristiyanto menuliskan "sikap kita kepada bumi bergantung kepada sikap kita kepada Tuhan yang menciptakan bumi" ${ }^{3}$. Ungkapan tersebut menunjukkan bahwa teologi bukan sebatas membicarakan Tuhan saja, melainkan terekspresi dalam tindakan dan prakteknya yang berkaitan dengan alam serta lingkungan. Karena itu teologi perlu dimaknai sebagai the intellectual expression of religion ${ }^{4}$, sehingga pengertiannya menjadi luas dan relevan untuk merespon tantangan kontemporer termasuk di dalamnya isu ekologi atau lingkungan.

Dewasa ini, perhatian manusia terhadap kerusakan lingkungan makin membaik. "Era 60-an dan 70-an dianggap sebagai masa lahirnya kesadaran ekologis manusia. Sebab pada tahun-tahun inilah mulai terjadinya krisis ekologis di seluruh dunia dan terjadinya eksploitasi alam yang besarbesaran" 5. Seperti yang dicontohkan oleh Sonny Keraf yang mengungkapkan bahwa "telah terjadi deforestasi secara besar-besaran di berbagai belahan dunia sehingga luas hamparan hutan terus menurun dengan perkiraan laju deforestasi mencapai tujuh juta hektar per tahun"6.

Persoalan ini menjadi perlu dibahas, karena manusia seperti sudah kehilangan orientasi dalam urusannya dengan alam. Christopher William Hrynkow menuliskan "Ecologcial crisis" invokes the dearth of sustainability that is inherent in the cumulative impact of human existence

${ }^{3}$ Sunarko dan A. Eddy Kristiyanto. Menyapa Bumi Menyembah Hyang Ilahi (Yogya: Kanisius, 2008), 56

${ }^{4}$ Peter L Berger, Kabar Angin dari Langit: Makna Teologi dalam Masyarakat Modern, (Jakarta: LP3ES, 1991), xi

${ }^{5}$ Sunarko dan A. Eddy Kristiyanto. Menyapa Bumi Menyembah Hyang Ilahi, 138

${ }^{6}$ A. Sonny Keraf, Krisis Dan Bencana Bencana Lingkungan Hidup Global (Yogyakarta: Kanisius, 2010), 28. 
on the planet"7 (Krisis ekologis 'menyerukan kematian keberlanjutan yang melekat pada dampak kumulatif eksistensi manusia di planet ini). Pemanfaatan alam tanpa kontrol, serta pemahaman sikap yang keliru terhadap alam, perlu untuk dikoreksi.

Mencari penyebab kerusakan lingkungan hidup tidaklah mudah, karena "persoalan yang ada sangat kompleks dan saling berhubungan silang-silang antara satu dengan yang lain, tetapi tidak berarti tidak dapat dilakukan"8. Dalam penelitian ini, dikhususkan untuk mengungkap salah satu sumber persoalan tersebut, yaitu paradigma anthroposentris.

\section{Metode Penelitian}

Penelitian ini merupakan jenis penelitian kualitatif. Peneliti menggunakan metode deskriptif. Menurut Sumadi Surya Brata metode deskriptif adalah "penelitian yang bermaksud membuat pencandraan (deskripsi) mengenai situasi-situasi atau kejadian-kejadian" 9 . Untuk mengumpulkan data penulis melakukan penelitian kepustakaan atau studi pustaka dengan cara menganalisis buku-buku dan jurnal yang berhubungan dengan etika lingkungan. Studi pustaka ini kemudian oleh penulis digabungkan dengan pengamatan dan pengalaman lapang penulis selama ini. Berdasarkan kedua sumber itu, penulis melakukan refleksi dan membangun usulan pemikiran yang lebih bersifat teoritis. Skemanya adalah sebagai berikut:

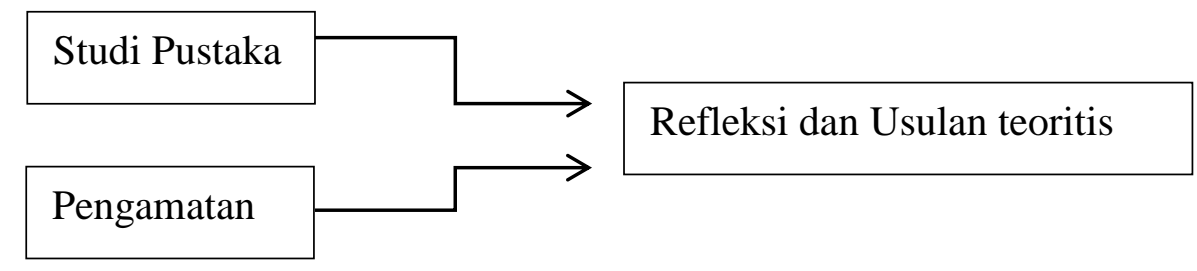

${ }^{7}$ Christopher William Hrynkow, "Greening God? Christian Ecotheology, Environmental Justice, and Socio-Ecological Flourishing," Environmental Justice 10, no. 3 (Juni 2017): 81, diakses 09 November 2018, https://doi.org/10.1089/env.2017.0009.

${ }^{8}$ Ferry Y. Mamahit, “Apa Hubungan Porong Dengan Yerusalah? Menggagas Suatu Ekoteologi Kristen". Jurnal Veritas 8/1 (April 2007), 4

9 Sumadi Surya Brata. Metodologi Penelitian. (Jakarta : Raja Grafindo persada.2002), 18 


\section{Pembahasan}

\section{Cara Manusia Memandang Alam Secara Umum}

Dalam etika lingkungan berkaitan dengan perilaku manusia terhadap alam, muncul beberapa teori. Sonny Keraf berpendapat ada 5 teori yaitu, antroposentri, biosentris, ekosentris, hak asasi alam dan ekofeminis ${ }^{10}$. Sekedar memberi sedikit pengetahuan, penjelasan kelima teori tersebut sebagai berikut: Antroposentri, merupakan teori etika lingkungan yang memandang manusia sebagai pusat alam semesta, dan hanya manusialah yang mempunyai hak untuk memanfaatkan dan menggunakan alam demi kepentingan dan kebutuhan hidupnya. Biosentris, teori ini menganggap "semua makluk hidup bernilai pada dirinya sendiri sehingga pantas mendapat pertimbangan dan kepedulian moral" ${ }^{11}$. Ekosentris, teori ini memusatkan etika lingkungan pada seluruh komunitas ekologis. Pandangan ini sering dianggap sebagai kelanjutan dari teori biosentris. Hak asasi alam, dalam pemikiran ini menerima bahwa "makluk hidup membutuhkan ekosistem atau habitat untuk hidup dan berkembang, dalam arti tertentu harus pula diterima bahwa makluk hidup di luar manusia mempunyai hak asasi atas ekosistem atau habitatnya" ${ }^{12}$. Ekofeminis, paradigma ini menawarkan telaah kristis atas sumber dari semua krisis lingkungan. Ekofeminisme sendiri merupakan cabang dari feminisme ${ }^{13}$ (dewasa ini feminisme telah berkembang dari sekedar perjuangan untuk diakui sebagai manusia yang memiliki rasio seperti layaknya laki-laki, feminisme berkembang menjadi gerakan yang memiliki aspirasi majemuk. Namun inti dari kesemua perjuangan tersebut adalah kesetaraan perempuan untuk menjadi subjek aktif dalam hidupnya ${ }^{14}$ ).

${ }^{10}$ A. Sonny Keraf, Etika Lingkungan, 2002.

${ }^{11}$ A.Sonny Keraf, Etika Lingkungan, 49.

${ }^{12}$ A. sonny Keraf, Etika Lingkungan, 121.

13 Feminisme merupakan aliran filsafat yang cenderung mempersoalkan, mempertanyakan dan menggugat cara pandang dominan, awalnya ditujuakan kepada cara pandang maskulin, patriakis juga hirarkis.

${ }^{14} \mathrm{Ni}$ Komang Arie Suwastini, "Perkembangan Feminisme Barat Dari Abad Kedelapan Belas Hingga Postfeminisme: Sebuah Tinjauan Teoretis," Jurnal Ilmu Sosial dan Humaniora 2, no. 1 (April 2013):206, diakses 09 November 2018, https://doi.org/10.23887/jish-undiksha.v2i1.1408. 


\section{Pendalaman Cara Pandang Antroposentrisme}

Antroposentrisme adalah teori etika lingkungan hidup yang memandang manusia sebagai pusat dari sistem alam semesta. Pandangan ini diikuti oleh pemikiran bahwa dunia diciptakan hanya untuk dan bagi kepentingan manusia ${ }^{15}$. Cara pandang ini menyebabkan manusia menguras alam demi memenuhi kepentingan dan kehidupannya tanpa memberi perhatian kepada kelestarian alam. Karena keuntungan menjadi tujuan utama, Franz Magnis Suseno mengkaitkan pemikiran antroposentris ini dengan "ekonomi kapitalis". "Dalam ekonomi kapitalis yang berorientasi pada laba, yang terjadi hanyalah pengeksploitasian terhadap sumber kekayaan alam..., menggali dan membongkar, tanpa memikirkan akibat bagi alam, ataupun meminimalkan resiko pencemaran, sebab hal itu akan meningkatkan biaya produksi" ${ }^{16}$. Kalau proses produksi kapitalisme dibiarkan, jelas alam lingkuangan hidup pasti akan semakin rusak. Karena itu, paradigma antroposentris dituduh sebagai penyebab utama kerusakan atau krisis lingkungan yang terjadi sekarang.

Untuk memahami teori yang dianggap biang keladi dari krisis lingkungan ini, perlu diketahui hal-hal yang sering dianggap sebagai akar berkembangnya. Faktor pemantik cara pandang yang antroposentris ini yakni, pertama, tafsiran keliru teks sakral agama kristen dalam kitab Kejadian. Kedua, filsafat barat (tradisi Aristotelian) dan seluruh tradisi pemikiran liberal, termasuk ilmu pengetahuan modern. Kisah penciptaan dalam kitab kejadian dan pemikiran besar dari filsuf-filsuf, sangat mempengaruhi cara pandang dan perilaku manusia modern terhadap alam dan lingkungan.

\section{Agama Kristen}

Dalam kitab Kejadian 1: 26-28 dituliskan "Berfirmanlah Allah: "Baiklah Kita menjadikan manusia menurut gambar dan rupa Kita, supaya mereka berkuasa atas ikan-ikan di laut dan burung-burung di udara dan atas ternak dan atas seluruh bumi dan atas segala binatang melata yang merayap

\footnotetext{
15 Haskarlianus Pasang, Mengasihi Lingkungan (Jakarta: Literatur Perkantas, 2011), 10.

${ }^{16}$ Franz Magnis Suseno, Berfilsafat Dari Konteks (Jakarta: Gramedia, 1991), 58
} 
di bumi." Maka Allah menciptakan manusia itu menurut gambar-Nya, menurut gambar Allah diciptakan-Nya dia; laki-laki dan perempuan diciptakan-Nya mereka. Allah memberkati mereka, lalu Allah berfirman kepada mereka: "Beranakcuculah dan bertambah banyak; penuhilah bumi dan taklukkanlah itu, berkuasalah atas ikan-ikan di laut dan burung-burung di udara dan atas segala binatang yang merayap di bumi."17

Dinyatakan bahwa Allah menciptakan manusia segambar dan serupa dengan Allah, dan manusia merupakan ciptaan-Nya yang tertinggi. Manusia mendapatkan mandat untuk mengusahakan dan memelihara alam. Allah menyerahkan alam semesta beserta isinya (termasuk hewan dan tumbuhantumbuhan) untuk dikuasai dan ditaklukkan. Ajaran ini telah interpretasikah bahwa "Allah memberi kewenangan penuh kepada manusia untuk mengeksploitasi alam demi kepentingannya. Manusia diberi hak oleh Tuhan sendiri untuk mengusai dan mengeksploitasi alam semesta serta segala isinya demi kehidupannya. "Perintah ini dimengerti sebagai pengesahan status manusia sebagai penguasa dunia yang acap kali dihubungkan dengan ide bahwa manusia adalah wakil Tuhan di dunia" 18. Ajaran ini menyebabkan manusia menjadi arogan dan bertindak sebagai penguasa yang lalim atas alam ini, dengan segala konsekuensi dan dampaknya yang merugikan" ${ }^{19}$. Drummond menduga "penafsiran seperti ini tampaknya didorong oleh keberhasilan ilmu pengetahuan dan inovasi teknologi dan kekuasaan manusia"20. Dari sini kemudian muncul ide subordinatif, manusia menentukan ciptaan lain.

Selanjutnya teks yang mendapatkan interpretasi melenceng lainnya yakni teks kitab Kejadian 2: 9 mengenai pohon pengetahuan di taman Firdaus. Teks tersebut berbunyi "Lalu TUHAN Allah menumbuhkan berbagai-bagai pohon dari bumi, yang menarik dan yang baik untuk dimakan buahnya; dan pohon kehidupan di tengah-tengah taman itu, serta pohon pengetahuan tentang yang baik dan yang jahat" ${ }^{21}$. Penafsiran

17 __ Alkitab (Jakarta: LAI, 2000),

18 Robert Setio, "Dari Paradigma 'Memanfaatkan' Ke 'Merangkul' Alam," Gema

Teologi 37, no.2 (31 Oktober 2013):165 http://journal

theo.ukdw.ac.id/index.php/gema/article/view/165.

${ }^{19}$ Sonny Keraf, Etika Lingkungan, 36-37

${ }^{20}$ Celia Deane-Drummond, Teologi dan Ekologi Buku Pegangan (Jakarta: BPK Gunung Mulia, 2011), 19 , Alkitab (Jakarta: LAI, 2000) 
terhadap teks ini salah satunya bahwa sebelum memakan buah terlarang, manusia secara otomatis taat dan patuh terhadap kehendak Allah. Namun, setelah memakan buat tersebut manusia menjadi terbuka matanya dan mengetahui mana yang baik dan mana yang buruk secara moral. Mereka tidak lagi patuh secara otomatis kepada perintah Allah melainkan memutuskan sendiri mana yang baik untuk dilakukan dan mana yang buruk yang harus dihindari. "Dalam kaitan dengan alam semesta, mereka mulai mengetahui makluk mana yang baik yang dapat dipelihara dan maklukmakluk mana yang kurang baik yang perlu dibasmi. Jadi yang baik adalah yang menunjang eksistensinya sebagai manusia sehingga harus dijaga dan dipelihara, sebaliknya yang jahat adalah yang mengancam kehidupannya di bumi sehingga harus dibasmi ${ }^{22}$.

Kedua hasil penafsiran teks di atas yang menjadi akar paradigma antroposentris mutlak perlu diperbaiki. Tujuannya guna meminimalisir praktek keliru, intervensi berlebihan manusia terhadap alam yang dapat berakibat fatal bagi seluruh kehidupan ciptaan. Pemahaman yang salah dapat menimbulkan reaksi atau sikap yang salah pula. Disinilah dibutuhkan reinterpretasi terhadap teks sakral dalam kitab Kejadian. Hasilnya diharapkan dapat dijadikan landasan dalam usaha memelihara dan melestarikan lingkungan.

\section{Tradisi Aristotalian.}

Pemikiran ini dikembangkan oleh Thomas Aquinas dengan fokus utama rantai kehidupan. Menurut paradigma ini, "semua kehidupan di bumi membentuk dan berada dalam sebuah rantai kesempurnaan kehidupan, mulai dari yang paling sederhana sampai kepada yang maha sempurna, yaitu Allah sendiri" 23 . Dalam rantai kehidupan posisi manusia menempati urutan teratas, berada di bawah Yang Maha Sempurna atau Tuhan. Kedudukan ini menempatkan manusia sebagai makluk yang lebih superior dibanding ciptaan lainnya. Ciptaan yang lebih rendah diperuntukkan bagi kepentingan makluk yang lebih tinggi. Makluk yang lebih tinggi mempunyai hak menggunakan makluk dibawahnya untuk memenuhi kebutuhan. Tumbuhtumbuhan dipersiapkan untuk hewan, hewan dan tumbuh-tumbuhan

${ }^{22}$ Keraf, Etika Lingkungan, 37.

${ }^{23}$ Sonny Keraf, Etika Lingkungan, 38. 
diperuntukkan bagi manusia. Dengan kata lain, manusia diperbolehkan memanfaatkan seluruh ciptaan sesuai kehendaknya dan sesuai kepentingannya.

\section{Kehendak bebas dan rasional yang dimiliki manusia}

Pada bagian ini manusia dipandang lebih tinggi dan lebih terhormat dibandingkan dengan makluk ciptaan lain kerena manusia adalah satusatunya makluk yang mempunyai kehendak bebas dan rasional. Manusia dilihat sebagai satu-satunya makhluk yang mampu menguasai dan menggerakkan aktivitasnya sendiri secara sadar dan bebas. Manusia adalah makluk berakal budi yang mendekati keilahian Tuhan. Dengan kemampuannya tersebut manusia dapat menentukan apa yang ingin dikerjakan dan memahami mengapa ia bertindak demikian. Lebih spesifik, Rene Descartes ${ }^{24}$ berpikiran manusia mempunyai tempat istimewa di antara semua makluk hidup, karena manusia mempunyai jiwa yang memungkinkannya untuk berpikir dan berkomuniasi dengan bahasa, sedangkan binatang tidak dan makluk lain tidak. Immanuel kant, berpendapat karena hanya manusia yang merupakan makluk rasional, manusia diperbolehkan secara moral untuk mengguakan makluk non rasional lainnya untuk mencapai tujuan hidup manusia yaitu mencapai suatu tatanan dunia yang rasional. Etika barat ini sangat antroposentris. Etika ini tidak berlaku bagi makluk lain di luar manusia. Oleh karena itu, tidak ada yang salah secara moral pada perilaku manusia terhadap binatang dan tumbuhan, serta makluk hidup lainnya, apapun perilaku manusia itu. Tepatlah apabila Imanuel Geovasky menuliskan "peradaban Eropa dengan pencerahaannya, mempunyai keyakinan yang kuat bahwa manusia mempunyai potensi yang amat besar untuk diperkembangkan, terlebih rasionya. Dengan rasionalitasnya, manusia bisa menguasai alam semesta. Alam ciptaan pun menjadi korban"25.

${ }^{24}$ Rene Descartes (1596-1650) adalah filsuf Perancis yang dijuluki "bapak filsafat modern", Ia peletak dasar aliran rasionalisme. Diambil dari kompasiana https://www.kompasiana.com/arilpratama/552e5bab6ea83406538b4573/alur-logika-renedescartes

${ }^{25}$ Imanuel Geovasky, "Kristologi Yang Bersahabat Terhadap Alam Ciptaan: Memandang Yesus Bersama Dengan Segenap Alam," Gema Teologi 35, no. 1/2 (Agustus 2012):130-131, diakses 10 Desember 2018, http://sac.ukdw.ac.id/journaltheo/index.php/gema/article/view/130-131. 


\section{Kedudukan Manusia Terhadap Alam}

Dalam ekologi, diyakini bahwa sistem alam (ekosistem) dan sistem sosial saling berhubungan. Manusia berada dalam sistem sosial (yang di dalamnya mencakup nilai, cara berpikir, paradigma, pengetahuan, ideologi, dan lain sebagainya) dan juga berada dalam ekosistem (yang terdiri dari air, tanah, udara, flora, fauna, alam, dan lain sebagainya). Kedua sistem ini saling berhubungan dan saling mempengaruhi. Manusia memegang peranan yang sangat menentukan bagi kelestarian atau keberlangsungan kehidupan di sekitarnya. Berkaitan dengan hubungan antara manusia dengan alam, Doglas John Hall seorang teolog dari Kanada kelahiran tahun 1928 memberikan tiga konsep pemikirannya yakni satu, manusia di atas alam. Dua, manusia di dalam alam. Tiga, manusia bersama alam ${ }^{26}$.

1. Manusia di atas alam. Pandangan ini ingin menjelaskan bahwa, keberadaan alam hanyalah untuk melayani manusia. Dari pandangan ini memunculkan sikap antroposentrime, dimana kepentingan manusialah yang menjadi modus utama dan menjadi ukuran dalam pengelolaan alam dan sumber kekayaannya, meskipun dengan dampak yang merusak alam lingkungan, menimbulkan pencemaran, termasuk menghasilkan desakralisasi. Pemikiran ini merupakan pandangan tradisional dan masih banyak dipegang banyak orang. Singkatnya, pandangan ini hanya memfokuskan diri pada kesejahteraan manusia dengan memanfaatkan alam seenaknya. Kebalikan dari sikap ini merupakan "pikiran animistik yang melebih-lebihkan kedudukan alam" 27 diikuti praktek-praktek sakralisasi. Biasanya dianut oleh agama-agama primitif timur. Segi positif dari menempatkan alam di atas manusia yaitu adanya sikap penghormatan terhadap alam. Alam dipandang sebagai rahim ibu bagi manusia, hewan, tumbuhan maupun materi-materi abiotik.

2. Manusia di dalam alam. Paradigma manusia di dalam alam memandang manusia sebagai bagian dari beribu-ribu ciptaan yang lain. Satu spesies di antara spesies lainnya, sama-sama terbatas, saling bergantung dan saling membutuhkan. Perbedaan dengan pandangan yang pertama pada bagian

${ }^{26}$ Doglas John Hall, The Steward a Biblical Symbol Come of Age dalam buku Polifonik Bukan Monofonik karangan Dr. Ebenhaizer I. Nuban Timo (Salatiga: Satya Wacana, 2015), 102

${ }^{27}$ Robert P. Borrong. Etika bumi baru (Jakarta: Bpk Gunung Mulia, 2003), 183 
ini manusia direduksi seolah-oleh sebagai mesin saja. Perbedaan yang lain, pada pemikiran ini manusia hanya didominasi (direndahkan).

3. Manusia bersama alam. Nisbah ini mau memperhatikan relasi di antara manusia dengan alam lingkungan. Disini manusia tidak superior atas segala ciptaan, tetapi juga tidak identik dengannya (direndahkan). Manusia bersama (disamping) ciptaan yang lain, di dalam solidaritas dengan ciptaan yang lain itu, meskipun tetap dalam perbedaanperbedaan. Manusia hidup bersama alam dan tidak memperlakukannya sesuka hati. Paradigma ketiga ini menjadi pandangan yang paling dekat dengan pandangan kekristenan terhadap alam. Atas dasar solidaritas, manusia memandang semua alam dan makluk lain secara integral. "Inilah dasar dari penatalayanan (stewardship) manusia dalam alam semesta. sebagaimana diciptakan Allah sebagai baik itu (kejadian 1: 10,12). Semua makluk hidup berada dalam relasi saling bergantung dan saling memerlukan". 28

Pendapat lain dikemukakan oleh Sudharto P. Hadi $^{29}$ menggambarkan bahwa hubungan manusia dengan alam dibedakan menjadi tiga tahap. Ketiga tahap itu yaitu:

a. Tahap satu : manusia tunduk kepada alam. Pada tahap ini manusia berhubungan langsung dengan alam dalam rangka memanfaatkan sumber dari alam (ini terjadi pada jaman hunting and gathering). Skemanya adalah sebagai berikut:

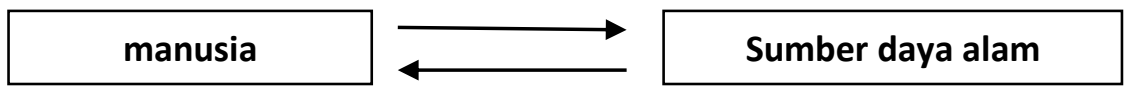

b. Tahap kedua : manusia menguasai alam. Dalam tahap ini manusia mulai menggunakan tehnologi untuk meningkatkan penguasaannya terhadap alam. Skemanya adalah sebagai berikut:

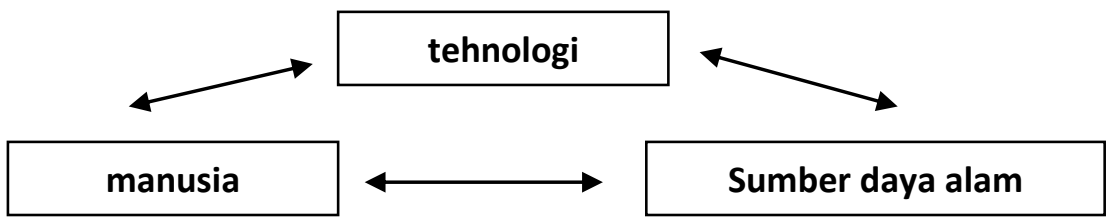

${ }^{28}$ Junus E.E Inabuy, Agama-agama Kerabat Dalam Semesta (Flores: Nusa Indah, 1994), 60-61

${ }^{29}$ Sudharto P. Hadi, Manusia dan Lingkungan (Semarang : Badan Penerbit Universitas Diponegoro, 2000), 13-16 
c. Tahap ketiga : tahap dimana manusia mulai mengorganisasi alam melalui tehnologi demi menghisap sumberdaya alam sebanyak-banyaknya. Skemanya adalah sebagai berikut:

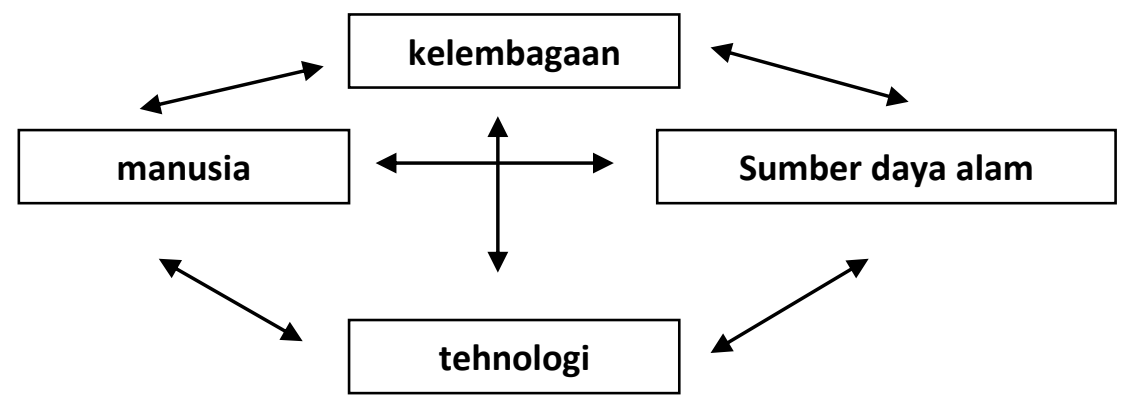

Akibat pengorganisasian tehnologi untuk memanfaatkan alam, maka timbullah hal-hal yang merusak dan menghancurkan lingkungan. Kelestarian lingkungan tidak mendapatkan perhatian yang memadai, interaksi sosial dan interaksi lingkungan diabaikan.

\section{Etika Lingkungan Mutlak Dibutuhkan}

Guna mencegah kerusakan lingkungan yang tak terkendali, etika lingkungan mutlak dibutuhkan. Fokus perhatian etika lingkungan melihat bagaimana manusia harus bertindak atau bagaimana perilaku manusia yang seharusnya terhadap lingkungan hidup. Norma atau kaidah yang mengatur perilaku manusia dalam berhubungan dengan alam serta nilai dan prinsip moral yang menjiwai perilaku manusia dalam berhubungan dengan alam tersebut. ${ }^{30}$ Pengertian di atas ingin memberikan pemaparan bahwa makluk non-manusia mendapatkan perhatian dalam etika ini. Lingkungan atau alam masuk sebagai bagian dari komunitas moral. Pada bagian ini perilaku moral manusia mengalami perluasan cara pandang.

Etika lingkungan merupakan kritik atas etika yang selama ini dianut oleh manusia yang dibatasi pada komunitas sosial manusia. Etika lingkungan hidup menuntut agar etika dan moralitas tersebut diberlakukan juga bagi komunitas biotis atau komunitas ekologis. Etika ini juga dipahami sebagai refleksi kritis tentang apa yang harus dilakukan manusia dalam menghadapi pilihan-pilihan moral yang terkait dengan isu lingkungan

${ }^{30}$ A. Sonny Keraf. Etika Lingkungan.(Jakarta: kompas, 2002), 26 
hidup. ${ }^{31}$ Senada dengan ini, Efri Roziati menuliskan etika lingkungan merupakan petunjuk arah bagi manusia untuk dapat mewujudkan moral yang baik bagi lingkungan mencakup menjaga kelestarian lingkungan hidup. ${ }^{32}$

\section{Perlu Interpretasi Teologi Penciptaan Yang Tepat}

Paradigma kristen mengenai hubungan manusia dengan alam yakni manusia merupakan bagian dari alam, tetapi pada sisi yang lain, manusia memang mempunyai keistimewaan. Manusia mendapat mandat dalam Kejadian 2:15 "TUHAN Allah mengambil manusia itu dan menempatkannya dalam taman Eden untuk mengusahakan dan memelihara taman itu". Pada bagian ini perlu mendapatkan perhatian yang tepat, supaya tidak terjadi kesalahan dalam interpretasi atau penafsiran.

Dalam pengakuan iman rasuli disebutkan "Aku percaya kepada Allah, Bapa yang mahakuasa, Khalik langit dan bumi”. Ini adalah sebuah pengakuan tentang Allah sebagai pribadi pencipta alam semesta. Pengakuan ini tidak dimaksudkan untuk menceritakan tentang proses terjadinya alam semesta, tetapi pengakuan tentang karya atau perbuatan-Nya dan juga eksistensi-Nya. Robert Borong menuliskan dengan memahami cerita penciptaan sebagai pengakuan iman, maka tidaklah relevan membandingkan apalagi mempertentangkan argumen kosmologis dari hasil penelitian ilmiah tentang teori kejadian alam dengan kebenaran kesaksian alkitab tentang alam yang diciptakan Allah. teologi kristen mengakui adanya permulaan waktu dan campur tangan ilahi dalam menciptakan alam semesta yang mencakup ruang, semua benda dan waktu ${ }^{33}$.

\section{Tuhan Adalah Perancang Dan Pencipta Terbaik}

Sejak awal penciptaannya, Tuhan menciptakan alam dengan baik. Dalam alam terdapat hukum-hukum yang membuat alam mempunyai kemampuan melakukan proses "siklus daur ulang" ${ }^{4}$. Seperti ungkapan

\footnotetext{
${ }^{31}$ Ibid, 27

${ }^{32}$ Efri Roziati. Biologi Lingkungan (Surakarta: Muhammadiah Universitas Press, 2017), 95

${ }^{33}$ Robert P. Borrong. Etika bumi baru, 181

34 Yang dimaksud dengan siklus daur ulang di sini, penulis menggunakan pengertian yang ungkapkan oleh Ituma. Yaitu sebuah kemampuan dari alam untuk
} 
Ezichi A. Ituma "God has created nature, designing some recycling process which maintains the equilibrium" 35 (Tuhan telah menciptakan alam, merancang beberapa proses daur ulang yang menjaga keseimbangan). Lebih lanjut, recycling process ini ada demi keseimbangan alam itu sendiri, sekaligus menunjukkan hikmat dari sang penciptanya. Dalam kisah penciptaan, alam diciptakan sedemikian rupa sempurna dan ditata oleh Allah, tujuannya supaya manusia dapat hidup dengan sebaik-baiknya. Sebagai Pencipta dan Pemilik ciptaan, Allah berkehendak untuk menyelenggarakan kelangsungan hidup semua ciptaan-Nya di dunia ini, di mana manusia dan ciptaan lain hidup berdampingan untuk memuliakan Dia, dan hidup dalam kerajaan shalom bersama ciptaan yang lain. ${ }^{36}$

\section{Segambar Dan Serupa Dengan Allah}

Diciptakan menurut gambar Allah tidak memberikan keistimewaan kepada manusia untuk menganiaya, mendominasi, mengeksploitasi tanpa batas ciptaan yang lain (antroposentris). Sebaliknya, "diciptakan menurut gambar Allah berarti manusia dipanggil untuk hidup dalam hubungan yang akrab dan pribadi dengan penciptanya sambil membangun komunitas harmonis dengan ciptaan yang lain" 37 . Seperti yang dituliskan Ezichi A. Ituma "If human beings obey God and respect natural order the world will remain

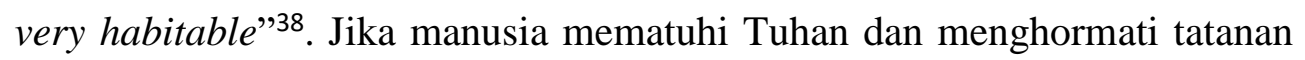
alam, dunia akan tetap sangat layak huni

\section{Manusia Berkuasa Atas Alam}

Teks dalam Kejadian 1:26-28 telah dijadikan dasar untuk upaya pemanfaatan alam secara tidak bertanggung jawab. Oleh golongan antroposentris, kata "berkuasa" dipahami secara literal dan dijadikan

melakukan proses yang terjadi terus-menerus atau berulang. Proses ini ada demi keberlansungan alam itu sendiri. Sebagai contoh: hujan (alamlah yang menghasilkan hujan, dan untuk alamlah hujan tersebut. Singkatnya proses dari alam, oleh alam dan untuk alam itu sendiri).

35 Ezichi A. Ituma, "Christocentric ecotheology and climate change," Open Journal of Philosophy, 1.A, $03 \quad$ (Februari 2013): 126, https://doi.org/10.4236/ojpp.2013.31A021.

${ }^{36}$ Ferry Y. Mamahit, "Apa Hubungan Porong Dengan Yerusalah? Menggagas Suatu Ekoteologi Kristen”. Jurnal Veritas 8/1 (April 2007), 15

${ }^{37}$ Irene Ludji. 32 Refleksi Ekoteologi (Salatiga, UKSW, 2014), 12

${ }^{38}$ Ezichi A. Ituma, "Christocentric ecotheology and climate change,"130 
legitimasi untuk bertindak sewenang-wenang. Teologi penciptaan menghindari literalisme. Teks tersebut berasal dari bahasa Ibrani radah (berkuasa), "dimengerti lebih kepada tugas untuk memelihara dan mengurus. Hal tersebut sesuai pula dengan Raja atau Gembala Timur Tengah Kuno yang memang bertugas mengatur dan mengupayakan agar rakyatnya hidup dalam damai dan sejahtera" ${ }^{39}$. Dapat pula diungkapkan bahwa alam dilihat tidak hanya sebagai fakta bilogis-fisik, melainkan sebagai keberadaan yang menjadi cerminan sang pencipta, yaitu Allah.

\section{Manusia Menaklukkan Alam}

Kata "menaklukkan" tidak boleh di tafsirkan secara negatif dan dijadikan landasan mengeksploitasi alam secara semena-mena (antroposentris). Ungkapan "menaklukkan" yang dalam bahasa Ibraninya (kabash) harus dipahami sebagai mengolah dan mengerjakan. Manusia melakukan tugas sebagai mitra Allah, sebagai kalifah yang bertanggung jawab atas alam dan segala makluk di dalamnya. "Ada pengawasannya, yang juga turut bekerja, yaitu Allah dan manusia bertanggung jawab terhadap sang pemberi kerja" ${ }^{40}$. Senada dengan Robert P. Borong, ada pula yang menuliskan "manusia adalah gambar Allah dalam pengertian menjadi wakil dan tanda kehadiran serta pemerintahan Allah di atas segenap ciptaan. Keberadaan manusia, dan tugasnya untuk berkuasa atas alam, adalah tanda atau "gambar" dari kedaulatan Allah atas semesta. Karena itu, tugas "penguasaan" yang dilakukan manusia mempunyai sifat penatalayanan."41

\section{Analisis}

Paradigma anthroposentris dengan prakteknya yang menguras alam tanpa memikirkan usaha pelestarian perlu dikritisi. Bila tidak ini sangat mempengaruhi hirarki dan fungsi manusia dalam kedudukannya bersama dengan alam. Penafsiran yang tepat terhadap teks yang sering kali dijadikan landasan oleh golongan anthroposentris merupakan salah satu caranya.

${ }^{39}$ Sunarko dan A. Eddy Kristiyanto. Menyapa Bumi Menyembah Hyang Ilahi, 33

${ }^{40}$ Robert P. Borrong. Etika bumi baru, 182.

${ }^{41}$ Tafsiran Sabda.

https://alkitab.sabda.org/commentary.php?book=Kej\&chapter=1\&verse=28\&cmt=full diakses pada 17 Juni 2019 pukul 23:21 
Lebih lanjut, dalam membangun teologi lingkungan hidup, seharusnya mengacu kepada ekoteologi yang theosentris (anthroposentris berpusat pada manusia, theosentris berpusat pada Allah) atau "back to religion". "Etika yang berpusat pada Tuhan ini (theosentris) melampaui etika

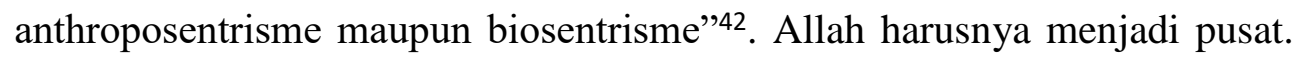
Karena usaha untuk mengelola dan melestarikan alam, tentu tidak dapat lepas dari Allah yang notebene adalah penciptanya. Penulis sangat setuju dengan analisis yang diungkapkan Rilus A. Kinsen yang menuliskan bahwa "yang menjadi akar krisis ekologi bukan ajaran Kristen itu sendiri, tetapi sebaliknya justru karena ajaran Kristen itu tidak dilaksanakan secara murni dan konsekuen" ${ }^{43}$. Dengan kata lain, penerapan etika theosentris meminimalisir krisis ekologi.

Pada sisi yang lain, perlu juga menyadarkan manusia, khususnya dalam kaitan "peran dan kedudukannya" di alam ini. Manusia memegang mandat budaya untuk menjaga alam. Manusia adalah representatif Allah dalam upaya pemanfaatan alam.

\section{Manusia Dicipta Untuk Menjaga Alam}

Manusia dicipta adalah untuk menjaga dan bukan merusak alam, itulah inti dari teologi penciptaan. Konsep tersebut penting untuk dimengerti sebagai mandat Ilahi. Karena itu, manusia mempunyai tanggung jawab terhadap kelestarian alam. Manusia perlu menghargai dan merawat alam. Selanjutnya dalam cara pandang kristen juga diyakini bahwa Tuhan adalah perancang dan pencipta terbaik, manusia diciptakan segambar dan serupa dengan Allah, manusia berkuasa atas alam. Di sinilah akan dilakukan koreksi atas interpretasi keliru dari pandangan antroposentris terhadap pokok-pokok tersebut.

\section{Perlu Tindakan Nyata Dari Kekristenan}

Guna mendukung gerakan pelestarian lingkungan, usaha pelestarian lingkungan perlu tindakan nyata dan terencana, sebagai usaha preventif maupun represif. Berikut ini merupakan usaha yang dapat dikerjakan baik

\footnotetext{
${ }^{42}$ Rilus A. Kinsen, "Faktor Etika Dalam Pengelolaan Sumberdaya Perikanan Di Indonesia". Jurnal Sosial Ekonomi dan Kelautan 4/2 (2009), 181.

${ }^{43}$ Rilus A. Kinsen, Jurnal Sosial Ekonomi dan Kelautan 4/2 (2009), 181.
} 
secara pribadi, dalam konteks keluarga dan konteks gereja sebagai aksi nyata melestarikan lingkungan.

a) Tanggung jawab pribadi

Dengan merusak alam ciptaan, manusia sebenarnya sedang menghancurkan peradaban dirinya sendiri. Sebagai perseorangan terkadang merasa bahwa tindakan kita tidak akan membuat banyak perbedaan, tetapi masalah-masalah akan berubah ketika banyak orang membuat keputusan yang sama tentang keselamatan dan keberadaan lingkungan. Hal konkrit yang dapat dilakukan secara pribadi yaitu misalnya mulai dari sikap diri yang peduli terhadap kebersihan dan keindahan alam disekitar kita, pengematan pemakaian sumber daya tidak tidakterbarukan, serta berikap kritis terhadap berbagai bentuk kegiatan yang bertolak belakang dengan semangat pelestarian lingkungan. Singkatnya secara pribadi kita perlu memperbaiki cara berelasi, berproduksi maupun cara mengkonsumsi. Beberapa tindakan praktis yang dapat dilakukan secara pribadi sebagai tindakan preventif di antaranya yakni mengembangkan akal budi dan gaya hidup yang berkelanjutan, meminimalkan penggunaan energi yang berdampak pada pemanasan global, meminimalkan polusi. Contoh praktis lainnya yaitu membuang sampah pada tempatnya, mengurangi penggunaan plastik, menanam pohon di lahan kosong sekitar rumah, dan lain sebagainya.

b) Tanggung jawab keluarga

Peran setiap individu anggota keluarga sangatlah penting dalam menentukan gaya hidup keluarga sehari-hari. Selain peran ayah sebagai kepala keluarga ada juga peran penting dan sangat strategis yang diemban seorang ibu dalam mengelola rumah dan bersama ayah mendidik anak terkait kebiasaan ramah lingan dalam keluarga. Salah satu contohnya yaitu konsep rumah berkelanjutan ${ }^{44}$ yang pada dasarnya bertujuan untuk mengoptimalkan pemanfaatan sumber daya alam yang

${ }^{44}$ Haskarlianus Pasang dalam bukunya "Mengasihi Lingkungan” halaman 216 memberikan definisi rumah berkelanjutan, yakni merupakan merupakan kombinasi dari kecintaan manusia terhadap alam, kearifan lokal dan kemajuan tehnologi. Rumah berkelanjutan menurut Michael mobbs mempunyai ciri tidak ada air hujan yang meninggalkan halaman rumah, artinya terdapat resapan air yang baik di area rumah tersebut. Tidak ada kotoran yang meninggalkan halaman rumah, artinya kebersihan terjaga dengan baik. Sampah dikelola dengan baik. Karakteristik yang lain, bangunan tersebut terbuat dari material yang ramah lingkungan, dll. 
melimpah yang disediakan Tuhan bagi kita, khususnya bagi kita yang tinggal di daerah tropis ${ }^{45}$.

c) Tanggung jawab gereja

Gereja dalam kedudukannya sebagai organisme ataupun organisasi mempunyai peranan vital dalam usaha pelestarian lingkungan. Gereja diharapkan dapat memberikan perhatiannya secara serius mengusahakan dan mengupayakan pemulihan kerusakan lingkungan ataupun pemanfaatan lingkungan yang baik. Banjir, hutan gundul, dapat tercegah ketika gereja menjalankan perannya. Kasus banjir di Sentani dimana gereja bertebaran dan kekirstenan sebagai agama mayoritas, akan lain ceritanya ketika gereja dapat menjalankan fungsinya dengan tepat.

Beberapa aksi praktis yang dapat dilakukan gereja antara lain mendukung program-program pemerintah dan pemerintah daerah dalam bidang lingkungan hidup. Dukungan ini dapat dilakukan dengan mendorong anggota jemaat untuk mendukung program pemerintah. Selain itu, gereja juga dapat melakukan kerjasama dengan pemeluk agama lain. Dalam kebersamaan dengan agama lain ini gereja dapat merumuskan hal-hal yang bisa dipahami bersama dengan pemeluk agama lain dalam aktifitas penyelamatan lingkungan. Sebagai contoh, pengelolaan sampah, memerangi penebangan liar dan eksploitasi sumberdaya alam secara berlebihan. Gereja perlu juga bekerja sama dengan LSM lingkungan, salah satu manfaatnya yakni gereja akan terbantu dalam pengembangan kapasitas warga gereja dalam hal kepedulian terhadap lingkungan. Gereja juga bisa "merumuskan pendekatan-pendekatan yang sesuai dengan konteks masyarakat atau kearifan lokal dan implementasi dalam kaitannya dengan pelestarian lingkungan dan sumber alam" ${ }^{46}$. Partisipasi nyata dalam kepedulian terhadap lingkuan hidup yang gereja dapat kerjakan yaitu mengambil bagian dalam peringatan hari-hari peringatan khusus yang terkait dengan linkungan hidup dengan mengadakan kebaktian khusus ${ }^{47}$. Dalam kaitan dengan tugas gereja mengajar umatnya, gereja juga dapat berperan 2011), 216.

${ }^{45}$ Haskarlianus Pasang, Mengasihi Lingkungan (Jakarta: Literatur Perkantas,

${ }^{46}$ Ibid, 250

${ }^{47}$ Ibid 
dengan membuat kurikulum pengajaran yang juga mengajarkan lingkungan. Gereja perlu mendidik umat tentang ekotelogi yang alkitabiah melalui kotbah-kotbahnya, sehingga umat dapat menghidupi dengan benar dan nyata, serta mempraktekkan secara konsisten. Bahkan dapat pula membentuk tim khusus yang memperhatikan lingkungan.

\section{Kesimpulan}

Memperjuangkan kelestarian lingkungan hidup bukanlah hal yang mudah. Ada pihak-pihak tertentu yang masih berparadigma antroposentris yang hanya berorientasi meraup keuntungan. Etika theosentris mutlak dibutuhkan guna melawan etika anthroposentris. Pada sisi yang lain, kekristenan perlu berpikir atau berteologi dengan menempatkan alam sebagai bagian integral dari karya penciptaan Allah. Konsep keselamatan perlu dilihat dengan "kacamata" yang lain, yakni secara holistik. Tidak ada keselamatan yang mengesampingkan kerusakan alam atau lingkungan. Teologi penciptaan perlu dipahami dan implementasikan sedini mungkin, bukan disalah tafsir demi melegalkan praktek eksploitasi alam (antroposentris). Kekristenan perlu mengajarkan perilaku konservasi atau pengelolaan alam yang baik. Gereja, keluarga dan setiap individu orang percaya mempunyai peran penting masing-masing dalam menjaga dan melestarikan lingkungan. Tidak cukup hanya dengan kesadaran, melainkan perlu disertai dengan aksi atau tindakan nyata. Baik dalam lingkup kecil ataupun skala besar.

\section{Daftar Pustaka}

Buku:

Berger, Peter L. Kabar Angin dari Langit: Makna Teologi dalam Masyarakat Modern. Jakarta: LP3ES, 1991.

Borrong, Robert P. Etika bumi baru. Jakarta: Bpk Gunung Mulia, 2003.

Brata, Sumadi Surya. Metodologi Penelitian. (Jakarta : Raja Grafindo persada.2002), 18

Drummond, Celia Deane. Teologi dan Ekologi Buku Pegangan. Jakarta: BPK Gunung Mulia, 2011.

Hadi, Sudharto P. Manusia dan Lingkungan. Semarang : Badan Penerbit Universitas Diponegoro, 2000 
Hall, Doglas John. The Steward a Biblical Symbol Come of Age dalam buku Polifonik Bukan Monofonik. Ebenhaizer I. Nuban Timo. Salatiga: Satya Wacana, 2015.

Inabuy, Junus E.E. Agama-agama Kerabat Dalam Semesta. Flores: Nusa Indah, 1994.

Keraf, Sonny. Krisis Dan Bencana Bencana Lingkungan Hidup Global. Yogyakarta: Kanisius, 2010.

Ludji, Irene. 32 Refleksi Ekoteologi. Salatiga, UKSW, 2014.

Pasang, Haskarlianus. Mengasihi Lingkungan. Jakarta: Literatur Perkantas, 2011.

Roziati, Efri. Biologi Lingkungan. Surakarta: Muhammadiah Universitas Press, 2017.

Sunarko dan A. Eddy Kristiyanto. Menyapa Bumi Menyembah Hyang Ilahi. Yogyakarta: Kanisius, 2008.

Suseno, Franz Magnis. Berfilsafat Dari Konteks. Jakarta: Gramedia, 1991.

Tristanto, Lukas Awi. Panggilan Melestarikan Alam Ciptaan. Yogyakarta: Kanisius, 2015.

Jurnal :

Geovasky, Imanuel. "Kristologi Yang Bersahabat Terhadap Alam Ciptaan: Memandang Yesus Bersama Dengan Segenap Alam," Gema Teologi 35, no. 1/2 (14 Agustus 2012),130-140, diakses 10 Desember 2018, http://sac.ukdw.ac.id/journal-theo/index.php/gema/article/view/130131.

Guess, Deborah. "An Ecotheological Exploration of the Thought of Arthur Peacocke," Journal of Anglican Studies 15, no. 2 (Februari 2017): 188-206, diakses $09 \quad$ November 2018. https://doi.org/10.1017/S1740355316000279.

Hrynkow, Christopher William. "Greening God? Christian Ecotheology, Environmental Justice, and Socio-Ecological Flourishing," Environmental Justice 10, no. 3 (Juni 2017): 81-87, diakses 09 November 2018, https://doi.org/10.1089/env.2017.0009.

Kinsen, Rilus A. "Faktor Etika Dalam Pengelolaan Sumberdaya Perikanan Di Indonesia". Jurnal Sosial Ekonomi dan Kelautan 4/2 (2009), 181. 
Mamahit, Ferry Y. "Apa Hubungan Porong Dengan Yerusalah? Menggagas Suatu Ekoteologi Kristen”. Jurnal Veritas 8/1 (April 2007), 4.

Ituma, Ezichi A. "Christocentric ecotheology and climate change," Open Journal of Philosophy, 1.A, 03 (Februari 2013): 126-130, diakses 09 November 2018, https://doi.org/10.4236/ojpp.2013.31A021.

Setio, Robert. "Dari Paradigma 'Memanfaatkan' Ke 'Merangkul' Alam," Gema Teologi 37, no. 2 (Oktober 2013):163-174, http://journal-theo.ukdw.ac.id/index.php/gema/article/view.

Suwastini, Ni Komang Arie. "Perkembangan Feminisme Barat Dari Abad Kedelapan Belas Hingga Postfeminisme: Sebuah Tinjauan Teoretis," Jurnal Ilmu Sosial dan Humaniora 2, no. 1 (April 2013): 198-208, diakses 09 November 2018. https://doi.org/10.23887/jishundiksha.v2i1.1408.

\section{Internet:}

https://www.kompasiana.com/arilpratama/552e5bab6ea83406538b4573/alur -logika-rene-descartes

https://alkitab.sabda.org/commentary.php?book=Kej\&chapter=1\&verse $=28$ $\& \mathrm{cmt}=$ full diakses pada 17 Juni 2019 pukul 23:21 